Jurnal Ilmu Sosial dan Pendidikan (JISIP)

Vol. 6, No. 1 Januari 2022

e-ISSN : 2656-6753, p-ISSN: 2598-9944

DOI: 10.36312/ jisip.v6i1.2648/http://ejournal.mandalanursa.org/index.php/JISIP/index

\title{
Efektivitas Penerapan Aplikasi Dukcapil Ceria Mobile Dalam Upaya Mendukung Pemerintahan Berbasis Elektronik (E-Government)
}

\author{
Irma Sari Yuni ${ }^{1}$, M. Fachri Adnan ${ }^{2}$ \\ ${ }^{1}$ Mahasiswa Sarjana Ilmu Administrasi Negara, Universitas NegeriPadang \\ ${ }^{2}$ Dosen Sarjana Ilmu Administrasi Negara, Universitas Negeri Padang
}

\begin{abstract}
Article Info
Received 02Januari 2021

Publish 04 Januari 2022

Abstract

The research that was conducted started from the problem that there were still a small number of people who used the Ceria Mobile Dukcapil Application and the lack of socialization and understanding of the community in the use of the Ceria Mobile Dukcapil Application, so that there were still people who used the services of brokers. This study itself aims to determine the effectiveness of the application of the Dukcapil Ceria Mobile application in Padang Pariaman in an effort to support E-Government-based Government. As well as analyzing the factors that affect the effectiveness of the Ceria Mobile Dukcapil program. This

Keywords:

E-government,

Dukcapil Ceria Mobile,

Padang Pariaman study uses a qualitative approach with the method of descriptive, where data were collected through observation, interviews, and documentation studies. The validity of the data was tested by using source triangulation technique. The results of this study reveal the fact that the Dukcapil Ceria Mobile Application can be said to be ineffective in supporting electronic-based government (Egovernment) in Padang Pariaman Regency because people are still unfamiliar with this application, there are still obstacles. -obstacles such as the lack of socialization which makes the public as the main target of Dukcapil Ceria Mobile Application, they do not understand about this application as well as the steps to use it independently at home and there are also internet network problems that are still inadequate. On the other hand, there are still people who use the services of brokers to manage their residence documents.
\end{abstract}

\begin{tabular}{l} 
Info Artikel \\
\hline \\
Received 02 Januari 2021 \\
Publish 04 Januari 2022
\end{tabular}

Publish 04 Januari 2022

\begin{abstract}
Abstrak
Penelitian yang dilakukan ini beranjak dari permasalahan masih sedikitnya jumlah masyarakat yang memanfaatkan aplikasi Dukcapil Ceria Mobile ini serta kurangnya sosialisasi dan pemahaman masyarakat dalam penggunaan aplikasi Dukcapil Ceria Mobile ini sehingga mengakibatkan masih terdapat masyarakat yang menggunakan jasa calo. Penelitian ini sendiri bertujuan untuk mengetahui sejauh mana efektivitas penerapan aplikasi Dukcapil Ceria Mobile yang diterapkan di Padang Pariaman dalam upaya mendukung Pemerintahan berbasis E-Government. Serta menganalisis faktor-faktor yang mempengaruhi efektivitas program Dukcapil Ceria Mobile. Penelitian ini menggunakan pendekatan kualitatif dengan metode deskriptif, dimana data dikumpulkan melalui observasi, wawancara, dan studi dokumentasi. Uji keabsahan data dilakukan dengan Teknik triangulasi sumber. Hasil penelitian ini mengungkapkan fakta bahwa Secara keseluruhan aplikasi Dukcapil Ceria Mobile ini bisa dikatakan aplikasi Dukcapil Ceria Mobile ini bisa dikatakan belum efektif dalam upaya mendukung pemerintahan berbasis elektronik (E-government) di Kabupaten Padang Pariaman karena masyarakat masih awam dengan aplikasi ini, masih terdapat kendala-kendala seperti sosialisasinya yang dinilai masih kurang yang membuat masyarakat sebagai sasaran utama dari adanya aplikasi Dukcapil Ceria Mobile belum memahami mengenai aplikasi ini begitu juga dengan langkah-langkah menggunakannya secara mandiri dirumah serta terdapat juga kendala jaringan internet yang masih kurang memadai. Di sisi lain juga masih terdapatnya masyarakat yang masih menggunakan jasa calo untuk melakukan pengurusan dokumen kependudukannya.
\end{abstract}




\section{PENDAhUluaN}

Pemerintahan berbasis digital atau yang dikenal dengan Electronic government diawali dengan dikeluarkannya Instruksi Presiden Nomor 3 Tahun 2003 mengenai Kebijakan dan Strategi Nasional Pengembangan Electronic Government. Melalui penerapan e-government, Pemerintah memanfaatkan teknologi informasi guna menata sistem manajemen serta mengoptimalkan proses kerja di lingkungan pemerintah. Berdasarkan Instruksi Presiden No 3 Tahun 2003 ini juga dijelaskan bahwa penggunaan teknologi informasi dalam penerapan $e$ government yang dimaksud meliputi dua kegiatan yang sifatnya saling mempengaruhi. Pertama, aktivitas yang meliputi pengelolaan informasi, pengolahan data, proses kerja, serta sistem manajemen yang berjalan secara elektronis. Kegiatan kedua merupakan aktivitas yang berhubungan dengan pemberian pelayanan publik yang memanfaatkan kemajuan teknologi informasi. Sehingga masyarakat di seluruh wilayah dapat mengakses layanan publik dengan lebih cepat, murah dan mudah.

Salah satu upaya yang dilakukan guna mewujudkan e-government di Kabupaten Padang Pariaman adalah dengan diluncurkannya sebuah terobosan berupa aplikasi Dukcapil Ceria Mobile. Dukcapil Ceria Mobile ini sendiri merupakan wujud dari gagasan Dukcapil Go Digital yang digagas dalam Rapat Koordinasi Nasional I Kependudukan dan Catatan Sipil tahun 2019 di Makassar. Dimana dalam Rakornas ini Disdukcapil di semua tingkatan, baik kota, kabupaten, maupun Provinsi diminta untuk melakukan terobosan kebijakan guna mentransformasikan pelayanan publik ke ranah digital dengan kerangka besar Dukcapil Go Digital. Gagasan ini diejawantahkan dalam bentuk regulasi melalui penerbitan Permendagri No 7 Tahun 2019 mengenai Administrasi Kependudukan Secara Daring atau Online

Berdasarkan Surat Keputusan Kepala Disdukcapil Kabupaten Padang Pariaman No 23 tahun 2019, terdapat beberapa layanan administrasi kependudukan yang bisa dilakukan melalui aplikasi Dukcapil Ceria Mobile. Jenis pelayanan publik yang bisa diakses melalui aplikasi Dukcapil Ceria Mobile diantaranya meliputi : Permohonan pencetakan KTP elektronik, dimana didalamnya meliputi KTP elektronik baru, KTP elektronik yang hilang, penggantian KTP lama ke KTP elektronik, KTP elektronik yang rusak dan pencetakan KTP elektronik pengganti Surat Keterangan; Kartu Identitas Anak; Akta Kelahiran; Permohonan Pindah; Akta Kematian; layanan administrasi terkait Kartu Keluarga (KK) yang didalamnya meliputi perubahan KK, pembuatan KK Baru, Penggantian KK yang hilang ataupun pecah KK. Selain itu dalam aplikasi Dukcapil Ceria ini masyarakat juga bisa memanfaatkan Layanan Pengaduan Tamasya.

Data yang diperoleh oleh peneliti dari Disdukcapil Padang Pariaman per tanggal 23 April 2021 menunjukkan jumlah keseluruhan pengguna di Kabupaten Padang Pariaman dari aplikasi Dukcapil Ceria Mobile mencapai 59.836 pengguna. Dimana jika dibandingkan dengan jumlah penduduk padang pariaman yang berjumlah 431.224 ribu maka jumlah persentase pengguna aplikasi Dukcapil Ceria Mobile ini adalah 13,88 persen. Selain itu persentase pengguna aplikasi Dukcapil Ceria Mobile di semua nagari juga terlihat belum merata. Dimana rentang persentaseserapan pengguna Dukcapil Ceria Mobile di semua nagari berkisar antara 8,11 persen hingga 29,47 persen.

Hasil observasi peneliti di nagari-nagari di Kabupaten Padang Pariaman juga menemukan fakta bahwa masih terdapat masyarakat yang belum mendapatkan sosialisasi yang memadai terkait aplikasi Dukcapil Ceria Mobile. Dimana mereka baru mengetahui 
adanya layanan tesebut hanya pada saat mengajukan layanan administrasi kependudukan pada operator di nagari.

Sementara itu terdapat pula masyarakat yang karena ketidak-tahuan dan kesibukannya masih meminta bantuan orang lain (calo) untuk mengurus administrasi kependudukan. Padahal dengan adanya aplikasi Dukcapil Ceria Mobile, masyarakat dapat dengan mudah memanfaatkan smartphone mereka untuk menyelesaikan berbagai layanan administrasi kependudukannya dengan mudah dan gratis.

Merujuk pada uraian di atas, penulis mengidentifikasikan beberapa masalah terkait penerapan Dukcapil Ceria Mobile di Padang Pariaman. Pertama, terdapat kesenjangan persentase jumlah masyarakat yang menggunakan aplikasi Dukcapil Ceria Mobile di beberapa nagari hal ini diketahui melalui data yang didapatkan dari Dinas Dukcapil Kabupaten Padang Pariaman. Jika dibandingkan dengan nagari lain seperti Nagari Koto Dalam Selatan dengan persentase serapan pengguna sebesar 29,47\%, Nagari Kudu Gantiang 13,87\% dan Nagari Tandikek Selatan 8,11\%. Kedua, masih kurangnya sosialisasi penggunaan aplikasi Dukcapil Ceria Mobile kepada masyarakat terlihat dari sedikitnya jumlah pengguna hal ini diketahui dari wawancara awal yang peneliti lakukan dengan masyarakat dimana masyarakat tersebut tidak mendapatkan sosialisasi sehingga ia tidak tahu dan langsung mendatangi kantor dukcapil untuk melakukan pengurusan dokumen kependudukan namun di dinas dukcapil diarahkan untuk melakukan pengurusan secara online. Ketiga, masih banyak masyarakat yang belum bisa beradaptasi dengan teknologi baru khususnya aplikasi Dukcapil Ceria Mobile yang diketahui dari informasi yang diberikan oleh salah satu operator nagari yang menyatakan bahwa masyarkat banyak yang meminta tolong pada operator nagari dan belum mandiri dalam penggunaan aplikasi Dukcapil Ceria Mobile ini. Keempat, karena ketidaktahuan masyarakat, masih terdapat masyarakat yang memanfaatkan jasa calo yang diketahui dari wawancara dengan masyarakat, hal ini dikarenakan masyarakat malas melakukan pengurusan jauh ke kantor Dukcapil.

\section{KAJIAN PUSTAKA}

\section{Pengertian E-Government}

Menurut (Mulyadi, 2016) e-government didefenisikan pemanfaatan atau pengaplikasian teknologi informasi, spesialnya internet, guna membuat pelayanan publik menjadi lebih baik, berorientasi kepada konsumen, nyaman, serta efektif dari segi pembiayaan. Sementara menurut (Balilatfo, 2020), E- government adalah suatu inovasi berbasis pengembangan dalam penyelenggaraan sarana serta prasarana pemerintahan yang dengan memakai maupun menggunakan sistem elektronik untuk peningkatan suatu penyelenggaraan pelayanan publik dengan kualitas yang lebih baik, sehingga sanggup memberikan pelayanan kepada para pengguna jasa layanan secara efektif, efisien dan memuaskan.

Secara keseluruhan E-government dapat dilihat sebagai pengaplikasian TIK dalam proses penyelenggaraan pemerintahan yang berbasis elektronik. Tujuannya untuk meningkatkan efektivitas, efisiensi transparansi serta akuntabilitas pemerintah (Napitupulu, 2020). World bank dalam (Nawawi, 2013) juga memaparkan ruang lingkup dan domain $e$ government sebagai pemanfaatan teknologi informasi oleh government berupa computer mobile dan wide area network internet. Melalui pemanfaatan teknologi tersebut, hubungan antara pemerintah dengan sesame aparatur pemerintah, kelompok bisnis ataupun rakyat, dapat ditransformasikan dengan baik.

Berdasarkan beberapa pemahaman mengenai e-government sebagaimana yang diungkapkan oleh para ahli diatas, dapat ditarik kesimpulan bahwa e-government adalah proses penyelenggaraan tata kelola pemerintahan yang memanfaatkan teknologi informasi, terutama dalam pelayanan publik. Dimana hal ini bertujuan untuk memberikan pelayanan publik yang lebih baik serta lebih efektif dan efisien kepada masyarakat.

\section{Dukcapil Ceria Mobile}

Dukcapil Ceria Mobile adalah aplikasi berbasis android yang dapat di unduh di google 
play store yang memungkinkan masyarakat Kabupaten Padang Pariaman untuk mengajukan layanan administrasi kependudukan baik berupa pencatatan sipil ataupun perubahan dokumen serta mengakses pelayanan Dukcapil lainnya tanpa harus terbatasi oleh ruang dan waktu. (Perbup Nagita no 53 tahun 2019) Peluncuran aplikasi Dukcapil Ceria Mobile ini didasarkan pada gagasan Nagari Go Digital yang ditetapkan pada tanggal 5Oktober 2019 melalui surat keputusan Nomor :23/Kep/Disdukcapil/2019 mengenai Program Inovasi Nagari Go Digital Pada Dinas Kependudukan Dan Pencatatan Sipil Kabupaten Padang Pariaman yang dikeluarkan oleh Kepala Disdukcapil Kabupaten Padang Pariaman. Hal ini juga diperkuat dengan dikeluarkannya Peraturan Bupati Padang Pariaman Nomor 53 Tahun 2019 Tentang Inovasi Nagari Digital Administrasi Kependudukan yang Ditetapkan dan Diundangkan di Parit Malintang pada tanggal 22 Oktober 2019.

Keberadaan aplikasi Dukcapil Ceria Mobile ini bertujuan untuk memudahkan akses masyarakat dalam pelayanan di Disdukcapil Kabupaten Padang Pariaman. Sehingga melalui aplikasi Dukcapil Ceria Mobile masyarakat dimungkinkan untuk mengakses layanan administrasi pencatatan sipil ataupun dokumen kependudukan hanya dengan menggunakan smartphone yang mereka punya dari kediamannya, tanpa harus mendatangi lagi kantor Disdukcapil yang lokasinya relatif jauh. Dukcapil Ceria Mobile yang merupakan bentuk pengejawantahan dari Program Nagari Go Digital diluncurkan guna memastikan pelayanan publik di Kabupaten Padang Pariaman dapat meningkat kualitasnya. Terkhusus dalam menyederhanakan dan memangkas birokrasi sehingga pelayanan publik dapat diproses lebih cepat. Keberadaan aplikasi ini juga memangkas jarak yang harus ditempuh oleh masyarakat Ketika butuh mengakses pelayanan publik dari Disdukcapil. Sesuai dengan Pedoman Pelaksanaan Program Nagari Go Digital Bagi Pemerintah Nagari, Pelayanan administrasi kependudukan yang memanfaatkan aplikasi Dukcapil Ceria Mobile menjadi relatif dekat dan dapat dicetak langsung di kantor nagari setempat.

Fungsi ditetapkannya inovasi nagari digital di bidang administrasi kependudukan (NAGITA) termuat dalam Perbup Padang Pariaman Nomor 53 tahun 2019. Fungsi pertama, memangkas jarak dan mempercepat pelayanan dalam pengurusan dokumen kependudukan. Dimana masyarakat dimungkinkan untuk mengajukan layanan administrasu kependudukan dan mencetaknya cukup di kantor nagari setempat. Fungsi kedua, menghadirkan pemerintah ditengah-tengah masyarakat khususnya dalam bidang penyelenggaraan pencatatan sipil dan administrasi kependudukan. Motto pelayanan dari Dukcapil Ceria Mobile ini sendiri adalah "Siap melayani dengan CERIA". Dimana CERIA sendiri merupakan akronim dari Cepat, Efisien, Responsif, Inovatif dan Akuntabel.

\section{Teori Efektivitas}

Menurut (Subhki, Akhmad \& Jauhar, 2013) efektivitas merupakan ukuran berhasil tidaknya pencapaian tujuan organisasi. Suatu organisasi atau program dapat dikatakan berjalan secara efektif apabila ia berhasil mencapai tujuannya. Sementara menurut Siagian dalam (Mamuaja, 2016) efektivitas lebih dilihat sebagai pemanfaatan sarana dan prasarana serta berbagai sumber daya yang sebelumnya sudah ditetapkan guna melahirkan barang atau jasa dari kegiatan yang dijalankannya. Efektivitas menggambarkan sejauh mana sasaran yang telah ditetapkan berhasil dicapai. Dengan kata lain, semakin efektivitas akan semakin tinggii jika hasil kegiatan semakin mendekati sasaran.

Guna mengukur sejauh mana keefektifan sebuah program, menurut Sutrisno (Wulandari, 2018) terdapat beberapa indikator yang perlu diperhatikan. Indikator tersebut diantaranya adalah : 1) Pemahaman Program. 2) Ketepatan Sasaran 3) Ketepatan Waktu 4) Tercapainya Tujuan 5) Perubahan Nyata

\section{Faktor-Faktor yang Mempengaruhi Efektivitas Program}

Menurut (Kazmi, 2010), dalam upaya mewujudkan e-government terdapat beberapa faktor utama yang mempengaruhi efektif atau tidaknya implementasi e-government di lapangan. Faktor pertama adalah kualitas portal web (web portal quality). Faktor kedua adalah sejauh mana dukungan infrastruktur teknologi (technology infrastructure). Faktor ketiga 
adalah kebijakan Pemerintah (Government Policy) yang mendukung pelaksanaan $e$ government iru sendiri. Sedangkan faktor terakhir yang tidak kalah penting adalah faktor sumber daya manusia (human resources). Menurut (Budiani, 2017) ada 4 indikator yang mempengaruhi efetivitas sebuah program yaitu: 1) Ketepatan Sasaran Program, 2) Sosialisasi Program, 3) Tujuan Program, 4) Pemantauan Program.

Merujuk pada riset terdahulu yang dilakukan oleh (Farhani \& Adnan, 2021) Pelayanan dokumen kependudukan melalui sistem PADUKO dapat dikatakan sudah berjalan baik dilihat dari indikator efektivitas yang dikemukakan oleh $\mathrm{Ni}$ Wayan Budiani meskipun dalam beberapa indikator dan faktor-faktor yang mempengaruhi efektivitas PADUKO masih terdapat hambatan dalam pelaksanaan PADUKO.

(Dahlila \& Frinaldi, 2020), ditemukan hasil bahwa Penerapan Inovasi Digi Mobile dalam meningkatkan pelayanan publik Pada Dispenduk Kota Pariaman secara konsep inovasi dapat dikatakan memenuhi kriteria berhasil dan dikatakan efektif dan efisien. Hal ini dikarenakan sudah terdapat 4 faktor yang akan mempengaruhi keberhasilan penyelenggaraan inovasi. Keempat faktor tersebut antara lain: karakteristik inovasi (produk); faktor saluran komunikasi berupa kemudahan akses; faktor upaya perubahan dari agen berupa memfasilitasi perangkat desa; dan faktor sistem sosial.

Sementara itu juga terdapat riset (Tami \& Putri, 2019) yang meneliti tentang. Dimana hasil penelitiannya menunjukkan bahwa secara keseluruhan, efektivitas penerapan program ekelurahan di Kelurahan Silaing Bawah Kota Padang Panjang berdasarkan indikator pemahaman program, tepat sasaran, tepat waktu, tercapainya tujuan, dan perubahan nyata sudah berjalan dengan baik, namun belum sepenuhnya efektif.

Berdasarkan uraian permasalahan yang penulis paparkan sebelumnya, maka penulis menetapkan rumusan masalah dari penelitian ini. Rumusan masalah tersebut diantaranya adalah: 1) Bagaimanakah efektivitas penerapan aplikasi Dukcapil Ceria Mobile dalam upaya mendukung pemerintahan berbasis elektronik (E-government) di Kabupaten Padang Pariaman? 2) Faktor apakah yang mempengaruhi efektivitas penggunaan aplikasi Dukcapil Ceria Mobile di Kabupaten Padang Pariaman?

\section{METODE PENELITIAN}

Penelitian ini menggunakan pendekatan kualitatif dengan metode deskriptif. Penggunaan pendekatan kualitatif ini dikarenakan pendekatan ini dipandang lebih relevan dalam mengamati gejala-gejala sosial yang ada di masyarakat. Jenis penelitian deskriptif adalah penelitian yang berusaha menggambarkan fenomena yang terjadi secara nyata, realistis, aktual, nyata dan pada saat ini, karena penelitian ini untuk membuat deskripsi, gambaran atau lukisan secara sistematis, aktual dan akurat mengenai fakta-fakta, sifat-sifat serta hubungan antar fenomena yang dimiliki (Rukajat, 2018). Lokasi penelitian adalah di Kabupaten Padang Pariaman. Teknik pengumpulan data yang digunakan dalam penelitian ini adalah dengan cara pengamatan atau observasi, wawancara serta dokumentasi. Untuk uji keabsahan, peneliti menggunakan metode triangulasi. Sedangkan untuk teknik analisis data menggunakan catatan harian, transkrip, koding, kategorisasi, tema dan memos sebagaimana teknik yang dikemukakan oleh (Bungin, 2020).

\section{HASIL DAN PEMBAHASAN}

Efektivitas pelaksanaan program Dukcapil Ceria Mobile di ukur dengan menggunakan indikator yang dikemukakan oleh Sutrisno, yaitu pemahaman program, ketepatan sasaran, ketepatan waktu, tercapainya tujuan dan perubahan nyata. Dimana hasil penelitian penulis terhadap masing-masing indikator adalah sebagai berikut :

\section{a. Pemahaman Program}

Dalam penerapannya Dukcapil Ceria Mobile ini dari segi pemahanan program tokohtokoh masyarakat dari nagari-nagari yang ditemui mengetahui mengenai program Dukcapil 
Ceria Mobile, begitu juga dengan operator nagari dimana dalam indikator pemahaman program operator nagari sudah paham dengan aplikasi Dukcapil Ceria Mobile ini.

Namun kondisi ini justru bertolak belakang dengan pengetahuan masyarakat. Ada yang mengetahui namun banyak yang belum memahami bahkan mengetahui adanya aplikasi Dukcapil Ceria Mobile ini. Agar efektif perlu adanya perbaikan karena dilapangan penulis menemukan bahwa terdapat masyarakat yang masih awam dengan aplikasi Dukcapil Ceria Mobile ini. Masyarakat mengaku belum mendapatkan sosialisasi pihak nagari mengenai aplikasi Dukcapil Ceria Mobile ini. Sebagian masyarakat hanya tahu bahwa sudah dapat melakukan pengurusan dokumen kependudukan di nagari setempat tapi masyarakat tidak mengetahui bahwa adanya aplikasi yang dapat diakses secara mandiri dirumah dengan bermodalkan smartphone dan jaringan internet saja. Padahal seharusnya keberadaan dari tokoh masyarakat ini dapat diberdayakan untuk membantu dalam mensosialisasikan kepada masyarakat dikarenakan tokoh masyarakatlah yang dekat dengan masyarakat.

Hal ini sesuai dengan penelitian sebelumnya yang dilakukan (Farhani \& Adnan, 2021) yang mengatakan bahwa tidak semua masyarakat paham akan teknologi yang ada terutama masyarakat yang sudah berusia lanjut, selain itu tidak semua masyarakat memiliki HP android untuk mengakses layanan.

Menurut Sutrisno dalam (wulandari,2018) Indikator pemahaman program berkaitan dengan sejauh mana program tersebut dipahami oleh stakeholder terkait serta bagaimana proses realisasi suatu program agar dapat diterima dan dipahami dengan mudah. Melalui pemahaman program yang baik, program tersebut dalam proses pelaksanaannya tentu dapat dijalankan dengan mudah dan efektif. Pemahaman program ini tentunya harus dikuasai oleh semua pihak terkait. Terutama pihak yang terlibat langsung dalam pelaksanaan program tersebut.

Berdasarkan pengertian dari indikator pemahaman program diatas dapat diketahui bahwa pemahaman program Dukcapil Ceria Mobile ini masih kurang karena tidak semua stakeholder yang memahami mengenai aplikasi Dukcapil Ceria Mobile ini. Harus ada perbaikan karena ditemukan masyarakat belum memahami mengenai aplikasi ini begitu juga dengan langkah-langkah menggunakannya secara mandiri dirumah sehingga masyarakat tidak perlu meminta bantuan dari pihak nagari.

Ketidaktahuan masyarakat ini diketahui karena masyarakat tidak mendapatkan informasi mengenai adanya aplikasi ini, menurut pengakuan masyarakat, maasyarakat tidak mendapatkan sosialisasi langsung dari pihak pemerintah nagari sehingga tidak mendapatkan informasi. Menurut Heeks (dalam Napitulu,2020) terdapat 7 komponen yang menjadi area penting dan harus dikelola dengan baik agar penerapan e-government dapat berhasil dimana informasi merupakan salah satu faktornya, informasi yaitu faktor yang terkait dan prasyarat input dan output sistem. Informasi mengenai adanya suatu program sangatlah penting karna bagaimana mungkin masyarakat bisa berpartisipasi mensukseskan suatu program jika masyarakat itu tidak mengetahuinya.

Pihak nagari mengaku sudah berupaya melakukan sosialisi kepada masyarakat melalui wali korong serta pernah bersosialisi langsung dengan masyarakat dengan cara duduk di warung-warung untuk memberitahu masyarakat. Menurut pihak nagari salah satu faktor dari ketidaktahuan yang disampaikan masyarakat ini disebabkan oleh kesadaran masyarakat akan pentingnya dokumen kependudukan masih minim. Serta masyarakat yang cenderung malas untuk mengurus dokumen kependudukan sehingga menyebabkan terdapat masyarakat yang masih menggunakan jasa calo untuk mengurus dokumen kependudukan miliknya. Dinas Dukcapil Padang Pariaman mengaku sudah berupaya mengatasi masalah ini, salah satu upaya dinas dukcapil untuk memberantas calo adalah melalui aplikasi ini

Selajutnya berdasarkan hasil wawancara peneliti di nagari yang tingkat penyerapannya tinggi ditemukan fakta bahwa dari pihak nagarinya memang proaktif untuk mensosialisasikan aplikiasi Dukcapil Ceria Mobile ini kepada masyarakatnya. Dan juga di 
nagarinya sendiri yaitu Nagari Koto Dalam Selatan peneliti juga sudah menemukan alur pelayanan Dukcapil Ceria Mobile, kondisi berbeda ditemukan di dua nagari yang penyerapannya menengah dan rendah, dimana tidak adanya informasi mengenai aplikasi Dukcapil Ceria Mobile ini di kantor nagarinya.

Dalam penerapan suatu program sangatlah penting pemahaman dari pelaksana program itu sendiri maupun dari penerima program. Pengetahuan dari berbagai pihak terkait mengenai suatu program yang dikeluarkan sangat berdampak pada keberlangsungan dari program itu sendiri.

Dengan demikian dapat diketahui bahwa terkait pemahaman program Dukcapil Ceria Mobile ini masih kurang dikarenakan tidak semua stakeholder yang memahami mengenai aplikasi Dukcapil Ceria Mobile ini. Padahal keberadaan tokoh masyarakat ini sendiri sebenarnya dapat dirangkul dan diberdayakan untuk melakukan sosialisasi program ditengah masyarakat sehingga Dukcapil Ceria Mobile bisa menyentuh masyarakat secara keseluruhan tidak hanya pada tataran elit masyarakat ataupun tokoh masyarakat saja. Dengan perbaikan di beberapa aspek tersebut diharapkan Dukcapil Ceria Mobile ini dapat berjalan lebih efektif lagi kedepannya.

\section{b. Ketepatan Sasaran}

Sasaran Dukcapil Ceria Mobile ini adalah masyarakat namun dalam penerapannya masyarakat justru masih awam dan masih banyak yang belum bisa mengakses aplikasi Dukcapil Ceria Mobile ini. Dukcapil Ceria Mobile semestinya dapat membantu masyarakat serta mengurangi biaya-biaya yang tidak perlu.

Keberadaan aplikasi ini membuat orang tidak perlu datang lagi ke Dukcapil untuk melakukan layanan administrasi kependudukan. Sehingga masyarakat yang ingin melakukan layanan administrasi akan lebih hemat dari sisi waktu, tenaga dan biaya. Namun dalam pelaksanaanya ditemukan masyarakat yang tetap mendatangi kantor dukcapil dikarenakan ketidaktahuannya mengenai adanya aplikasi ini, masyarakat yang terlanjur datang ini akan diarahkan untuk mengakses layanan Dukcapil Ceria Mobile secara mandiri menggunkan ponsel pintar atau meminta bantuan dari pihak nagari asalnya, ini dikarenakan dinas dukcapil sendiri sudah tidak melayani pelayanan secara tatap muka terlebih disituasi pandemi kecuali untuk beberapa layanan tertentu seperti perekaman KTP serta layanan pengaduan. Hal seperti ini tentu sangat disayangkan karena seharusnya informasi itu sampai kepada masyarakat secara keseluruhan, tidak hanya pada tataran elit masyarakat saja.

Masih awam dan masih belum pahamnya masyarakat dalam mengakses aplikasi Dukcapil Ceria Mobile ini tentu berkaitan dengan sejauh mana sosialisasi yang didapatkan oleh masyarakat, dari hasil penelitian sosialisasi yang dilakukan oleh pemerintah sejauh ini masih kurang karena hanya secara lisan saja peneliti tidak menemukan spanduk yang terpajang di nagari ataupun himbauan tertulis yang secara khusus dibuatkan untuk memberitahu masyarakat mengenai adanya aplikasi ini.

Hal ini sesuai dengan penelitian terdahulu yang dilakukan oleh (Tami \& Putri, 2019) yang menyatakan bahwa sosialisasi program seharusnya lebih menekankan kepada masyarakat. Sehingga masyarakat bisa lebih memahami dan lebih mengerti mengenai program namun sampai saat ini sosialisasi yang dilakukan belum sepenuhnya terfokus kepada masyarakat secara umum.

Menurut sutrisno dalam (wulandari,2018) Indikator ketepatan sasaran berkaitan dengan peninjauan langsung terhadap keberadaan program. Dimana peninjauan menitikberatkan pada penilaian sejauh mana keberadaan program sesuai dengan aturan serta tepat sasaran. Apabila suatu program berjalan dan hasilnya sesuai dengan yang sudah ditetapkan sebelumnya, maka program tersebut dapat dinilai sudah berjalan dengan efektif.

Dalam penerapan aplikasi Dukcapil Ceria Mobile ini sasaran yang dituju dalam penerapannya adalah masyarakat. Masyarakat merupakan faktor penting berjalan atau tidaknya program karena masyarakatlah yang paling merasakan perubahan dalam pengurusan dokumen kependudukan. 
Dari wawancara yang peneliti lakukan dapat dikatakan bahwasanya dari aspek ketepatan sasaran program Dukcapil Ceria Mobile belum tepat sasaran. Bagi sebagian masyarakat yang mendapatkan dan mengerti cara penggunaanya adanya Dukcapil Ceria Mobile ini sangat membantu masyarakat serta mengurangi kerugian moril maupun material karna dengan adanya aplikasi ini orang tidak perlu ke dukcapil dokumen kependudukan. Namun masyarakat masih banyak yang awam dalam pengunaan aplikasi Dukcapil Ceria Mobile ini. Hal ini tentu berkaitan dengan sosialisasi yang dilakukan oleh pemerintah sejauh ini masih kurang.

Dapat disimpulkan bahwa aplikasi Dukcapil Ceria Mobile ini belum tepat sasaran karna dilapangan penulis menemukan bahwa masih ada kendala masyarakat yang masih awam dan belum memahami bagaimana menggunakan aplikasi maka dari itu perlu adanya perbaikan pada aspek sosialisasi.

\section{c. Ketepatan Waktu}

Dalam pengurusan menggunakan Dukcapil Ceria Mobile lamanya waktu penyelesaian surat itu sangat relative dan juga lamanya pengurusan surat menggunakan aplikasi Dukcapil Ceria Mobile ini tergantung pada berapa orang yang melakukan permohonan dan juga tergantung pada kualitas sinyal yang dimiliki. Biasanya pengurusan surat menggunakan aplikasi Dukcapil Ceria Mobile dapat tuntas dalam satu hari jika tidak ada kendala serta data yang diajukan lengkap, untuk pengurusan yang berkaitan perbaikan KTP itu agak sedikit memakan waktu untuk sampai ke tangan masyarakat karna KTP harus dikirim terlebih dahulu via pos oleh dinas dukcapil.

Menurut sutrisno dalam (wulandari,2018) Indikator ketepatan waktu juga merupakan salah satu indikator kunci dalam menilai sejauh mana keefektivan sebuah program berjalan. Dalam konteks ini semakin presisi suatu program berjalan sesuai dengan aturan waktu yang sudah direncanakan, maka semakin efektif terealisasi dari program tersebut.

Dengan demikian dapat dikatakan bahwa dengan menggunakan aplikasi Dukcapil Ceria Mobile ini Mobile lamanya waktu penyelesaian surat itu sangat relative hal ini tergantung pada berapa orang yang melakukan permohonan dan juga bagaimana pada kualitas sinyal yang dimiliki.

\section{d. Tercapainya Tujuan}

Tercapainya tujuan dari suatu program dapat dijadikan tolak ukur keberhasilan program tersebut. Berdasarkan penjelasan yag diberikan oleh pihak dukcapil selaku pembuat program diketahui bahwa tujuan dari adanya Dukcapil Ceria Mobile ini untuk memotong akses serta efisiensi biaya dari masyarakat sendiri. Hasil penelitian menunjukkan bahwa tujuan dari aplikasi Dukcapil Ceria Mobile ini bisa dikatakan belum sepenuhnya tercapai, dengan adanya Dukcapil Ceria Mobile ini masyarakat tidak perlu lagi datang ke kantor Dukcapil untuk melakukan pengurusan administrasi kependudukan cukup dirumah saja dengan memanfaatkan smartphone, atau masyarakat hanya perlu datang ke kantor Wali Nagari setempat, tanpa perlu ke kantor Dukcapil. Namun faktanya dilapangan sebagian masyarakat mengaku tidak mengetahui adanya aplikasi ini ketidaktahuan masyarakat ini tentu berpengaruh pada minat masyarakat untuk melakukan pengurusan dokumen kependudukan, masyarakat yang mengira pengurusan dokumen kependudukan masih berbelit serta memakan waktu dan biaya tentu enggan untuk melakukan pengurusan dokumen kependudukan miliknya.

Bahkan juga ditemukan masyarakat yag karena ketidaktahuannya langsung mengunjungi kantor dukcapil untuk melakukan pengurusan dokumen kependudukan padahal pengurusan itu sudah dilakukan secara online oleh pihak dukcapil.

Selain itu juga masih terdapat masyarakat yang menggunakan jasa calo dalam pengurusan dokumen kependudukannya sehingga dari segi efisiensi tidak didapatkan oleh masyarakat tersebut karena ia harus mengeluarkan uang untuk membayar jasa calo. Selanjutnya berdasarkan hasil wawancara diketahui bahwa masyarakat masih awam mengenai aplikasi ini terutama masyarakat yang belum melek teknologi dan sudah tua, hal 
ini disebabkan karena kurangnya sosialisasi kepada masyarakat.

Menurut sutrisno dalam (wulandari,2018) Tujuan dari suatu program dapat dikatakan tercapai apabila hasil dari kegiatan atau program sesuai dengan tujuan-tujuan awal yang sudah ditetapkan. Semakin banyak manfaat dari program dan semakin mendekati capaian tujuan awal dari program tersebut, maka program ataupun kegiatan yang diselenggarakan dapat dikatakan berjalan dengan efektif.

Hal ini berdasarkan penelitian sebelumnya oleh (Farhani \& Adnan, 2021) yang mengatakan bahwa ukuran tercapai atau tidaknya tujuan dari aplikasi dapat dilihat dari masyarakat sudah paham dan mengerti apa aplikasi itu dan sudah banyak masyarakat yang mengurus dokumen kependudukan melalui aplikasi itu.

Dapat disimpulkan bahwa tujuan dari aplikasi Dukcapil Ceria Mobile ini untuk memotong akses masyarakat belum tercapai karena untuk mengaksesnya mandiri masyarakat masih awam dengan aplikasi ini hal ini dikarenakan kurangnya sosialisasi yang diberikan kepada masyarakat sehingga masyarakat itu tidak tau dan tidak paham menggunakan aplikasi ini dan sebagian malah memilih jasa calo yang otomatis mengeluarkan biaya sementara ada aplikasi Dukcapil Ceria Mobile yang dapat digunakan secara gratis.

\section{e. Perubahan Nyata}

Dengan adanya aplikasi Dukcapil Ceria Mobile ini tentu diharapkan mendatangkan perubahan nyata bagi baik masyarakat, admin nagari maupun dari pihak dukcapilnya sendiri. Dari segi masyarakat yang mengetahui mengenai adanya aplikasi ini tentu merasakan perubahannya, dimana sebelumnya harus jauh ke dinas dukcapil dan mengatri untuk mendapatkan pelayanan namun sekarang sekarang dapat mengakses dan mengurus sendiri dokumen kependudukannya tetapi bagi masyarakat yang tidak mengetahui perubahan itu belum ia rasakan. Berbagai inisiatif e-gov tidak aka nada gunannya jika tidak ada pihak yang merasa diuntungkan dengan adanya implementasi konsep tersebut (indrajit,2016).

Berdasarkan hasil penelitian, masyarakat yang mengetahui mengenai adanya aplikasi ini adalah masyarakat yang memiliki hubungan dengan pihak nagari sehingga ia lebih cepat dalam mendapatkan infomasi, tokoh-tokoh masyarakat serta masyarakat yang mengetahui saat mendatangi Kantor Wali Nagari ataupun Dukcapil. Hal ini sangat disayangkan karena jika informasi dapat menyentuh seluruh lapisan masyarakat akan memungkinkan masyarakat lebih terdorong untuk memperbaiki dokumen kependudukan yang selama ini sering bermasalah seperti data yang ganda dan sebagainya

Selanjutnya dari segi pemerintah nagari dalam penerapannya aplikasi Dukcapil Ceria Mobile ini membuat pihak nagari dapat membantu masyarakatnya dalam pengurusan dokumen kependudukan karna admin/operator di Nagari memiliki peran penting dalam terselenggaranya aplikasi ini. Pihak nagari sebagai yang paling dekat dengan masyarakat seharusnya lebih dapat menjangkau masyarakatnya seperti memberikan himbauan kepada masyarakat secara khusus, menyebarkan selebaran atau memasang spanduk di kantor nagari sebagai informasi bagi masyarakat. Namun kondisi dilapangan justru hal ini belum optimal dilakukan. Bahkan ditemukan nagari yang tidak menunjukan adanya tanda-tanda keberadaan aplikasi ini. Berdasarkan hasil wawancara juga diketahui bahwa alasan dari pihak nagari belum melakukan sosialisasi kepada masyarakat adalah terkait masalah anggaran yang lebih difokuskan untuk covid dan juga kondisi jaringan internet yang kurang memadai mempengaruhi peran nagari dalam rangka mensukseskan aplikasi ini.

Hal ini sesuai dengan hasil penelitian terdahulu yang dilakukan oleh (Dahlila \& Frinaldi, 2020) yaitu infrastruktur sinyal dan jaringan apalagi jika cuaca yang kurang bersahabat maka akan hilang yang menyebabkan aplikasi tidak tadat diakses sama sekali dan beberapa daerah yang tidak dapat mengakses sinyal dengan baik.

Selanjutnya dari pihak dukcapil kabupaten Padang Pariaman sendiri menyatakan bahwa adanya Dukcapil Ceria Mobile ini membuat pelayanan di kantor dukcapil berubah 
karena hampir sudah tidak melayani masyarakat secara tatap muka. Sejauh ini upaya yang dilakukan oleh pihak dukcapil adalah menyebarkan informasi melalui media sosial seperti facebook, instagram, youtube dll.

Menurut sutrisno dalam (wulandari,2018) Indikator perubahan nyata juga menjadi salah satu tolok ukur keefektifan program. Semakin banyak manfaat dan perubahan di masyarakat dengan adanya program tersebut menunjukkan bahwa program tersebut berjalan dengan efektif. Pelaksanaan program ini tentunya tidak hanya menimbulkan perubahan positif, tapi juga dapat saja menimbulkan perubahan dalam arti negatif.

\section{Faktor-faktor yang mempengaruhi efektivitas:}

\section{1) Kualitas Portal Web}

Kualitas portal web yang dimiliki oleh Dukcapil Ceria Mobile ini untuk segi kualitas sudah bagus dan masyarakat bisa dengan gampang mengakses aplikasi ini. Namun untuk pegaksesannya tergantung pada jaringan. Hal ini sesuai dengan penelitian terdahulu yang dilakukan oleh (Dahlila \& Frinaldi, 2020) dimana aplikasi yang digunakan sangat mudah diakses serta tidak membutuhkan waktu yang lama dalam mendaftarkan berkas hanya cukup dengan mengupload foto bukti persyaratan.

Dari wawancara yang peneliti lakukan aplikasi ini terkadang ada maintenance aplikasi yang membuat aplikasi tidak bisa diakses sama sekali. Hal yang sama juga disampaikan pihak dukcapil bahwa aplikasi ini beberapa kali ada trouble, seperti kebijakan dari dukcapil pusat harus menambah beberapa item sehingga lebih meningkatkan keamanan.

Dapat disimpulkan bahwa kualitas portal web dari aplikasi Dukcapil Ceria Mobile ini sudah bagus hanya saja untuk pengaksesanya terkadang terkendala sinyal internet.

\section{2) Infrastruktur Teknologi}

Infrastruktur teknologi merupakan suatu faktor penting dalam berjalan tidaknya suatu program yang berbasis online. Berdasarkan wawancara dan observasi yang peneliti lakukan di beberapa nagari untuk Nagari Kudu Gantiang jaringan yang ada disana sudah cukup bagus dan juga di nagarinya terdapat wifi jadi untuk masalah jaringan Nagari Kudu Gantiang ini tidak ada masalah. Untuk Nagari Koto Dalam Selatan di kantor nagarinya jaringan lancar karena mereka memakai net one, namun masih terdapat dua korong yang tidak memiliki akses jaringan jadi masyarakat mengurusnya ke nagari. Selanjutnya di Nagari Tandikek Selatan jaringan internet masih kurang memadai, dari pengakuan operator nagari bahwa Nagari Tandikek Selatan belum mempunyai akses jaringan internet sehingga Ia menggunankan jaringan data pribadi, susahnya jaringan untuk melakukan pengurusan pada aplikasi Dukcapil Ceria Mobile berpengaruh pada lamanya proses upload dokumen yang dilakukan oleh nagari.

Hal ini sesuai dengan hasil penelitian terdahulu yang dilakukan oleh (Dahlila \& Frinaldi, 2020) yaitu infrastruktur sinyal dan jaringan apalagi jika cuaca yang kurang bersahabat maka akan hilang yang menyebabkan aplikasi tidak tadat diakses sama sekali dan beberapa daerah yang tidak dapat mengakses sinyal dengan baik.

Terkait kendala jaringan yang dikeluhkan oleh nagari, pihak Dukcapil menanggapi hal ini sebagai tanggung jawab bersama yang juga membutuhkan komitmen dari nagari itu sendiri untuk menghadirkan jaringan yang lebih baik. Hal ini dikarenakan akses jaringan yang baik tidak hanya dapat digunakan untuk pengurusan aplikasi Dukcapil Ceria Mobile namun dapat digunakan untuk keperluan lain oleh nagari setempat.

Menurut hasil kajian dan riset dari Harvard JFK School of Government (dalam indrajit, 2016) support merupakan elemen utama dan paling krusial yang harus dimiliki oleh pemerintah adalah keinginan dari berbagai kalangan untuk benar-benar menerapkan konsep e-government.

Terkait permasalahan sinyal, butuh kerjasama dengan dinas kominfo untuk mempercepat pembangunan infrastruktur digital. Hal ini sesuai dengan program presiden 
tentang membangun tol langit, menyediakan akses infrastruktur digital yang memadai untuk seluruh masyarakat indonesia. Sehingga kominfo pun harus proaktif untuk mendorong pembangunan infrastruktur digital.

\section{3) Kebijakan Pemerintah}

Kebijakan pemerintah sendiri terkait dengan aplikasi ini didasarkan pada gagasan Nagari Go Digital yang ditetapkan pada tanggal 5 Oktober 2019 melalui Keputusan Kepala Dinas Kependudukan Dan Pencatatan Sipil Kabupaten Padang Pariaman Nomor :23/Kep/Disdukcapil/2019 tentang Program Inovasi Nagari Go Digital Pada Dinas Kependudukan Dan Pencatatan Sipil Kabupaten Padang Pariaman. Hal ini juga diperkuat dengan dikeluarkannya Peraturan Bupati Padang Pariaman Nomor 53 Tahun 2019 Tentang Inovasi Nagari Digital Administrasi Kependudukan yang Ditetapkan dan Diundangkan di Parit Malintang pada tanggal 22 Oktober 2019.

Menurut indrajit dalam (Hardono, 2016) dukungan dari pemerintah merupakan landasan utama untuk terbentuknya dari pemerintah. Selanjutnya mengenai tindak lanjutnya di nagari diketahui belum ada dari nagari yang mengeluarkan peraturan nagari terkait dengan aplikasi Dukcapil Ceria Mobile ini.

Dapat disimpulkan bahwa dukungan dari pemerintah sangatlah perlu dalam hal ini pemerintah nagari seharusnya membuatkan kebijakan atau strategi-strategi khusus yang dapat menunjang efektifnya program Dukcapil Ceria Mobile ini.

\section{4) Sumber Daya Manusia}

Sumber Daya Manusia yang terlibat adalah berbagai pihak seperti masyarakat sebagai penerima layanan serta operator di nagari yang bertugas dalam konfirmasi layanan serta dari pihak dukcapil sendiri dimana terdapat Back Office Team (BOT) atau operatornya di dinas Dukcapil yang bertugas terkait berjalannya aplikasi Dukcapil Ceria Mobile ini.

Menurut heeks (dalam napitulu,2020) ketersediaan SDM yang terampil dan kecukupan pelatihan yang disediakan untuk menggunkan sistem merupakan salah satu komponen yang berkontribui terhadap kesuksesan dan kegagalan e-government.

Dari segi masyarakat seperti yang peneliti temui dilapangan, masyarakat itu cenderung belum terlalu paham menggunakan aplikasi Dukcapil Ceria Mobile ini secara mandiri dan masih membutuhkan pihak nagari untuk pengurusan serta karakteristik masyarakat yang tidak mau ribet dalam melakukan pengurusan mandiri. Selanjutnya dari SDM di nagari berdasarkan hasil wawancara kemampuan staff IT dan SDM yang ada di nagari sudah memadai dalam menggunakan aplikasi ini begitu juga dengan operator di disdukcapil.

Menurut indrajit (dalam Hardono,2016) Sumber daya pegawai yang handal menjadi penentu sukses atau tidaknya program e-government. Oleh karena pemerintah harus dapat menjaring sumber pegawai yang memiliki etos kerja baik.

Dalam penerapan aplikasi Dukcapil Ceria Mobile ini, sumberdaya manusia yang ada seperti masyarakat masih kurang memadai dikarenakan masyarakat masih banyak yang belum dapat melakukan pengurusan secara mandiri di rumah dan membutuhkan pihak nagari untuk pengurusan serta karakteristik masyarakat yang tidak mau ribet dalam melakukan pengurusan mandiri, namun segi kemampuan operator di nagari serta operator di dinas dukcapil sudah memadai dalam menggunakan aplikasi ini.

\section{KESIMPULAN}

Berdasarkan hasil penelitian dan pembahasan yang telah dilakukan, maka dapat disimpulkan bahwa : 1)Untuk mewujudkan efektivitas program perlu adanya usaha bersama dari berbagai elemen yang terlibat, dalam hal ini adalah masyarakat, Operator Nagari serta Dinas Dukcapil Kabupaten Padang Pariaman. aplikasi Dukcapil Ceria Mobile ini bisa dikatakan belum efektif dalam upaya mendukung pemerintahan berbasis elektronik ( $e$ government) di Kabupaten Padang Pariaman karena masyarakat masih awam dengan aplikasi 
ini, masih terdapat kendala-kendala seperti sosialisasinya yang dinilai masih kurang serta masyarakat sebagai sasaran utama dari adanya aplikasi Dukcapil Ceria Mobile belum memahami mengenai aplikasi ini begitu juga dengan langkah-langkah menggunakannya secara mandiri dirumah. Di sisi lain juga masih terdapatnya masyarakat yang menggunakan jasa calo untuk melakukan pengurusan dokumen kependudukannya. 2) Faktor-faktor yang mempengaruhi efektivitas program Dukcapil Ceria Mobile ini dari segi sumber daya manusia yang bertugas dalam pengoperasiannya sudah cukup baik. Namun di masyarakat sendiri masih terkendala rendahnya literasi digital serta kendala jaringan internet yang masih kurang memadai. Sehingga masih banyak masyarakat yang cenderung belum bisa untuk mengakses dan menggunakan aplikasi ini secara mandiri. Di sisi lain juga terdapat sebagian karakteristik masyarakat yang enggan melakukan mengurus secara mandiri atau tidak mau ribet. Hal ini juga yang mendasari masih terdapatnya masyarakat yang menggunakan jasa calo untuk melakukan pengurusan dokumen kependudukannya.

\section{SARAN}

1. Pemerintah Nagari bersama Dinas Dukcapil harus saling bekerjasama dalam peningkatan sosialisi kepada masyarakat dengan cara seperti membuatkan spanduk di tempat-tempat umum serta diharapkan dapat memberikan sosialisai lebih intens agar lebih banyak masyarakat yang mengetahui dan paham dengan penggunaan aplikasi ini.

2. Terkait permasalahan jaringan internet yang dikeluhkan masih belum memadai, butuh komitmen dari semua stakeholder untuk mengakselerasi infrastruktur digital. Terlebih kebutuhan akan akses internet yang memadai juga dibutuhkan untuk menunjang kemajuan diberbagai sektor lainnya, terutama dalam menghadapi revolusi 4.0.

\section{DAFTAR PUSTAKA}

Balilatfo. (2020). Pelayanan Kependudukan Berbasis E-government Di Desa Triharjo Kabupaten Sleman Daerah Istimewa Yogyakarta. Kementrian Desa PDT dan Transmigrasi.

Budiani, N. W. (2017). Efektivitas Program Penanggulangan Pengangguran Karang Taruna "Eka Taruna Bhakti" Desa Sumerta Kelod Kecamatan Denpasar Timur Kota Denpasar. Jurnal Ekonomi Dan Sosial (INPUT), 2(1), 49-57.

Bungin, B. (2020). Post-Qualitative Social Research Methods: Kuantitatif- Kualitatif-Mix Methods. Prenadamedia Group.

Dahlila, D., \& Frinaldi, A. (2020). Inovasi Dukcapil Digi Mobil Dalam Meningkatkan Pelayanan Publik Pada Dinas Kependudukan Dan Pencatatan Sipil Kota Pariaman. JESS (Journal of Education on Social Science), 4(2), 241. https://doi.org/10.24036/jess.v4i2.285

Farhani, A., \& Adnan, M. F. (2021). Efektivitas Pelayanan Dokumen Kependudukan Melalui Sistem Paduko. JESS (Journal of Education on Social Science), 5(1), 66. https://doi.org/10.24036/jess.v5i1.300

Hardono, W. (2016). Analisis Kualitas Dan Efektivitas E-government Sebagai Media Pelayanan Publik Di Pemerintah Daerah Istimewa Yogyakarta Tahun 2015. Jurnal Ilmu Sosial Dan Ilmu Politik $U M Y, 1-15$.

Indrajit, R. E. (2016). Konsep dan Strategi Electronic Government. Andi Yogyakarta.

Kazmi, S. N. A. (2010). Factors influencing e-Governance implementation: Issues and challenges in Pakistan. 2010 5th International Conference on Digital Information Management, ICDIM 2010, 326-331. https://doi.org/10.1109/ICDIM.2010.5664643

Mamuaja, B. (2016). Analisis Efektivitas Penerapan Sistem Pengendalian Intern Terhadap Kinerja Instansi Pemerintah Di Dinas Pendapatan Kota Manado. Jurnal EMBA: Jurnal Riset Ekonomi, Manajemen, Bisnis Dan Akuntansi, 4(1).

Mulyadi, D. (2016). Studi Kebijakan Publik dan Pelayanan Publik: Konsep dan Aplikasi Proses Kebijakan Publik Berbasis Analisis Bukti Untuk Pelayanan Publik. Alfabeta.

Napitupulu, D., Lubis, M. R., Revida, E., Putra, S. H., Saputra, S., Negara, E. S., \& Simarmata, J. (2020). E-Government: Implementasi, Strategi dan Inovasi. Yayasan Kita Menulis.

Nawawi, Z. (2013). Manajemen Pemerintahan. PT Raja Grafindo Persada.

Rukajat, A. (2018). Pendekatan penelitian kuantitatif. Deepublish.

Subhki, Akhmad \& Jauhar, M. (2013). Pengantar Teori dan Perilaku Organisasi. Prestasi Pustaka Publisher. 
Tami, F. D., \& Putri, N. E. (2019). Efektivitas Penerapan Program E-Kelurahan Di Kelurahan Silaing Bawah Kota Padang Panjang. Spirit Publik: Jurnal Administrasi Publik, 14(1), 56. https://doi.org/10.20961/sp.v14i1.34004

Wulandari, K., Wibawa, S., \& Kuntjoro, B. (2018). Efektivitas Program Desa Yang Didanai Oleh Apbn ( Dana Desa ). JMAN Jurnal Mahasiswa Administrasi Negara, 2(1), 150-158., 02(01), 150-158. 